\title{
Pengaruh Pendidikan Angka Harapan Hidup dan Jumlah Penduduk Terhadap Pertumbuhan Ekonomi di Negara dengan Jumlah Penduduk Terbesar di Dunia
}

\author{
Muhammad Dedat Dingkoroci Akasumbawa1, Abd. Adim², Muhammad Ghafur \\ Wibowo ${ }^{3}$ \\ ${ }^{123}$ Fakultas Ekonomi \& Bisnis Islam, UIN Sunan Kalijaga Yogyakarta \\ 1'dedat.dingkorocy@gmail.com \\ ${ }^{2}$ abdadim07@gmail.com \\ 3 muhammad.wibowo@uin-suka.ac.id
}

\begin{abstract}
Abstrak
Tujuan penelitian ini untuk menguji pengaruh Pendidikan sekolah dasar, angka harapan hidup, dan jumlah penduduk terhadap pertumbuhan ekonomi. Penelitian ini menggunakan metode data panel dengan sampel di 5 negara dengan jumlah penduduk terbesar di dunia tahun 2015-2019. Data penelitian diambil dari situs resmi Word Bank. Hasil penelitian menunjukkan bahwa Pendidikan sekolah dasar berpengaruh positif terhadap pertumbuhan ekonomi. Angka harapan hidup menunjukkan pengaruh yang positif terhadap pertumbuhan ekonomi. Serta jumlah penduduk berpengaruh positif terhadap pertumbuhan ekonomi.
\end{abstract}

Kata Kunci: Pendidikan, Angka Harapan Hidup, Jumlah Penduduk, Pertumbuhan Ekonomi

\section{Abstract}

The purpose of this study was to test the influence of primary school education, life expectancy, and population on economic growth. This study used panel data method with samples in 5 countries with the largest population in the world in 2015-2019. The results showed that elementary school education has a positive effect on economic growth. Life expectancy figures show a positive influence on economic growth. As well as the population has a positive effect on economic growth.

Keywords: Education, Life Expectancy, Population, Economic Grwoth 


\section{Pendahuluan}

Pada bidang ekonomi, pengetahuan dianggap sebagai seperangkat keterampilan dan kemampuan yang dapat digunakan untuk menghasilkan barang baru (Ali et al, 2018). Dalam banyak literatur tentang pertumbuhan endogen, pengetahuan diwujudkan pada manusia yang disebut sebagai modal manusia. Akibatnya, pengetahuan dalam bentuk Pendidikan dan kemampuan dibutuhkan dalam mendorong pertumbuhan ekonomi (Ali et al, 2018).

Pendidikan telah lama dipandang sebagai penentu penting kesejahteraan ekonomi suatu negara (Hanushek \& Ludger, 2020). Pendidikan dapat meningkatkan sumber daya manusia yang akan meningkatkan produktivitas tenaga kerja dan tingkat pertumbuhan ekonomi (Habibi \& Mohamad, 2020). Meskipun investasi adalah alternatif dalam ekonomi yang dapat menghasilkan pertumbuhan ekonomi yang lebih besar, hal tersebut tidak akan mengurangi kontribusi penting. Pendidikan menjadi salah satu alasan mengapa sebagian besar negara berkembang tidak mendapatkan manfaat penuh dari kemajuan teknologi yang mana tidak dapat menjadi negara maju.

Kemajuan dan kemakmuran suatu negara tergantung pada pilihan pendidikan yang tersedia bagi bangsanya. Pendidikan tidak hanya melatih manusia untuk memahami dan mengatasi kompleksitas pertumbuhan ekonomi, tetapi juga berfungsi sebagai pengungkit untuk peningkatannya (Zhua et al, 2017). Penelitian yang dilakukan Habibi \& Mohamad (2020) mengemukakan bahwa pendidikan berpengaruh positif terhadap pertumbuhan ekonomi.

Angka harapan hidup merupakan salah satu indikator utama kesehatan penduduk dan perkembangan ekonomi suatu negara (Mahumud et al, 2013). Kematian berkorelasi dengan pertumbuhan ekonomi suatu negara, negara dengan berpenghasilan tinggi biasanya memiliki tingkat kematian yang lebih rendah dari pada negara yang lebih miskin (Shkolnikov et al, 2019). Oleh karena itu, perbaikan harapan hidup dapat meningkatkan pendapatan nasional yang kemudian dapat mencerminkan pertumbuhan ekonomi yang baik. Penelitian yang dilakukan oleh Okumade \& Ahmad (2020) mengemukakan bahwa angka harapan hidup berpengaruh negatif terhadap pertumbuhan ekonomi. Sedangkan penelitian yang dilakukan oleh Shkolnikov et al (2019) mengemukakan bahwa angka harapan hidup berpengaruh positif terhadap pertumbuhan ekonomi.

Majunya atau tidaknya suatu negara dapat dilihat dari pertumbuhan penduduknya (Peter \& Ibarahim, 2018). Jika dilihat dari banyaknya jumlah penduduk didunia, China adalah negara yang mempunyai jumlah penduduk terbanyak yaitu 1.406.640.000 jiwa yang mewakili $18,3 \%$ dari populasi penduduk dunia, kemudian disusul oleh India dengan 1.368.530.000 jiwa yang mewakili $17,8 \%$ dari populasi penduduk dunia, selanjutnya Amerika Serikat dengan 334.559.000 jiwa yang mewakili 4,36\% dari populasi penduduk dunia, lalu Indonesia menduduki jumlah penduduk terbanyak ke empat yaitu 268.074.600 jiwa yang mewakili 3,49\% populasi penduduk dunia, disusul oleh Pakistan dengan jumlah penduduk 221.707.000 jiwa yang mewakili 2,89\% dari populasi penduduk dunia. Di peringkat ke enam dengan jumlah penduduk 213.993.000 jiwa adalah Brazil yang mewakili 2,79\% dari total populasi dunia (www.worldbank.com).

Menurut Rodriguez et al (2016), pertumbuhan populasi yang cepat dapat menyebabkan pertumbuhan ekonomi dan menimbulkan kemiskinan yang lebih rendah. Penelitian yang dilakukan oleh Peter \& Ibrahim (2018) mengemukakan bahwa jumlah 
penduduk berpengaruh positif terhadap pertumbuhan ekonomi.

Berdasarkan penjelasan diatas, maka tujuan dari penelitian ini adalah untuk menguji hubungan Pendidikan, Angka harapan hidup, dan jumlah penduduk terhadap pertumbuhan ekonomi pada 5 negara dengan jumlah penduduk terbanyak tahun 2010-2019.

\section{Kerangka Pemikiran Teoritis Dan Perumusan Hipotesis}

\section{Kerangka Pemikiran}

Gambar 1 menunjukkan variabel dependen pada penelitian ini yaitu pertumbuhan ekonomi diproksikan dengan Produk Domestik Bruto (PDB) yang selanjutnya disebut dengan Y. Variabel independen dalam penelitian ini yaitu Pendidikan yang diproksikan dengan jumlah murid sekolah dasar (X1), kemudian angka harapan hidup (X2), dan jumlah penduduk (X3).

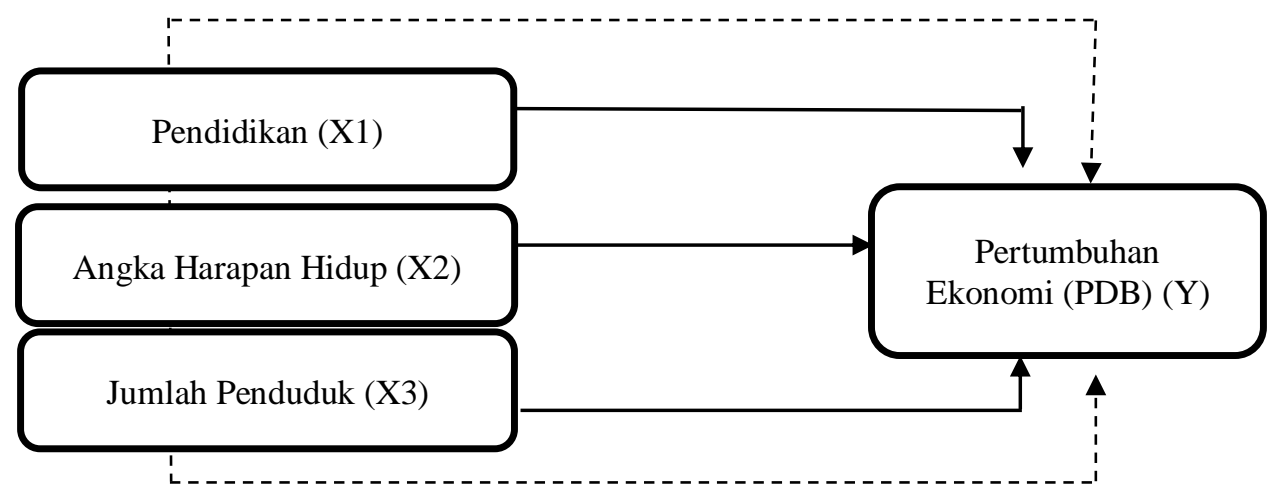

Gambar 1. Kerangka Pemikiran

Hubungan secara simultan

Hubungan secara parsia

\section{Hipotesis Penelitian}

Hipotesis pertama yaitu mengenai hubungan Pendidikan terhadap pertumbuhan ekonomi. Kemajuan dan kemakmuran suatu negara tergantung pada pilihan Pendidikan yang tersedia bagi bangsanya. Pendidikan tidak hanya melatih manusia untuk memahami dan mengatasi kompleksitas pertumbuhan ekonomi, tetapi juga berfungsi sebagai pengungkit untuk peningkatannya (Zhua et al, 2017). Penelitian yang dilakukan Habibi \& Mohamad (2020) mengemukakan bahwa pendidikan berpengaruh positif terhadap pertumbuhan ekonomi.

H1 : Pendidikan berpengaruh positif terhadap pertumbuhan ekonomi

Hipotesis kedua mengenai hubungan angka harapan hidup terhadap pertumbuhan ekonomi. Angka harapan hidup merupakan salah satu indikator utama kesehatan penduduk dan perkembangan ekonomi suatu negara (Mahumud et al, 2013). Kematian berkorelasi dengan pertumbuhan ekonomi suatu negara, negara dengan berpenghasilan tinggi biasanya memiliki tingkat kematian yang lebih rendah dari pada negara yang lebih miskin (Shkolnikov et al, 2019). Oleh karena itu, perbaikan harapan hidup dapat meningkatkan pendapatan nasional yang kemudian dapat mencerminkan pertumbuhan ekonomi yang baik. Penelitian yang dilakukan oleh Shkolnikov et al (2019) mengemukakan bahwa angka harapan hidup berpengaruh positif terhadap pertumbuhan ekonomi. 
Hipotesis terakhir mengenai hubungan jumlah penduduk terhadap pertumbuhan ekonomi. Majunya atau tidaknya suatu negara dapat dilihat dari pertumbuhan penduduknya (Peter \& Ibarahim, 2018). Menurut Rodriguez et al (2016), pertumbuhan populasi yang cepat dapat menyebabkan pertumbuhan ekonomi dan menimbulkan kemiskinan yang lebih rendah. Penelitian yang dilakukan oleh Peter \& Ibrahim (2018) mengemukakan bahwa jumlah penduduk berpengaruh positif terhadap pertumbuhan ekonomi.

H3 : Jumlah penduduk berpengaruh positif terhadap pertumbuhan ekonomi.

\section{Metode Penelitian}

\section{Data dan Sampel}

Penelitian ini merupakan penelitian kausal yang bertujuan untuk mengetahui pengaruh variabel independen terhadap variabel dependen dengan studi kuantitatif. Populasi penelitian ini adalah seluruh negara di dunia. Sampel penelitian adalah 5 negara dengan jumlah penduduk terbanyak didunia yaitu China, India, Indonesia, Pakistan dan Amerika Serikat. Data sekunder dalam penelitian ini dikumpulkan dari situs resmi world bank (wordbank.com).

\section{Metode Analisis Data}

Dalam penelitian ini data yang digunakan adalah data panel. Uji regresi data panel ini digunakan untuk mengetahui hubungan antara variabel independen yang terdiri dari Pendidikan yang diproksikan dengan jumlah murid sekolah dasar, angka harapan hidup dan jumlah penduduk terhadap pertumbuhan ekonomi yang di proksikan dengan PDB

Model regresi data panel dalam penelitian ini sebagai berikut:

Yit $\quad=\alpha+\beta_{1} X_{1 \text { it }}+\beta_{2} X_{2 \text { it }}+\beta_{3} X_{3 \text { it }}+\varepsilon_{\text {it }}$

Keterangan:

$\mathrm{Y} \quad=$ variabel dependen $(\mathrm{PDB})$

$\alpha \quad=$ konstanta

$\mathrm{X} 1=$ Pendidikan

$\mathrm{X} 2 \quad=$ angka harapan hidup

$\mathrm{X} 3=$ Jumlah penduduk

e $=$ errorterm

$\mathrm{t} \quad=$ waktu

\section{Tahapan Analisis Data}

Untuk menganalisis data penel diperlukan uji spesifikasi model yang tepat untutk memilih salah satu cara dari tiga pendekatan (Amyulianthy \& Elsa, 2016: 10). Pertama memilih antara Common Effect Model vs Fixed Effect Model, dengan cara memilih modal mana yang lebih cocok antara keduanya, yaitu dengan menggunakan Uji Chow (Uji $\mathrm{F}$ terbatas). Kedua, memilih antara Fixed Effect Model vs Random Effect Model, yaitu memilih mana yang lebih cocok antara keduanya, dengan cara menggunakan uji Hausman Test. Ketiga, memilih antara Common Effect Model vs Random Effect Model, dengan cara memilih model mana yang lebih cocok antara kedua, yaitu dengan menggunakan Lagrange Multiplier Test (LM Test).

\section{Hasil Dan Pembahasan}

Tabel 1 menunjukkan statistik deskriptif mengenai variabel yang digunakan dalam penelitian ini. Dari tabel tersebut nilai rata-rata PDB sebesar 27,94 yang menunjukkan bahwa dari kelima negara tersebut, PDB nya sudah dianggap baik. Pendidikan sekolah dasar pada kelima negara sampel memiliki nilai rata-rata sebesar 61.063.455 jiwa. Kemudian, nilai rata- 
rata angka harapan hidup pada kelima negara sampel sebesar $70,47 \%$, ini menunjukkan bahwa angka harapan hidup di negara tersebut telah baik yaitu telah melebihi $50 \%$. Jumlah penduduk memiliki nilai rata-rata sebesar 633.182.167 yang menandakan bahwa penduduk di negara sampel sudah cukup banyak.

\section{Uji Hipotesis dan Pemilihan Model}

Sebelum melakukan uji hipotesis, diperlukan untuk memilih model yang tepat dari uji data panel dengan menggunakan Uji Chow, Uji Hausman, dan Uji LM. Berdasarkan uji pemilihan model pada penelitian ini, model yang paling baik adalah Model Fixed Effect (FEM), namun pada uji asumsi klasik, model penelitian terkena masalah heteroskedastisitas dan autokorelasi. Sehingga, model yang paling tepat adalah model Generalized Least Square (GLS) (Yapono \& Situ, 2018).

Tabel 1. Statistik Deskriptif

\begin{tabular}{|l|l|l|l|l|l|}
\hline Variabel & N & Mean & Minimum & Maximum & Std. Deviasi \\
\hline PDB & 75 & 27.93825 & 25.73511 & 30.07659 & 1.213743 \\
\hline Pendidikan & 75 & 61063455 & 15618932 & $1.46 \mathrm{E}+08$ & 49785318 \\
\hline Angka Harapan Hidup & 75 & 70.46615 & 63.95100 & 77.48700 & 3.968854 \\
\hline Jumlah Penduduk & 75 & $6.50 \mathrm{E}+08$ & $1.60 \mathrm{E}+08$ & $1.40 \mathrm{E}+09$ & $5.42 \mathrm{E}+08$ \\
\hline Valid N & $\mathbf{7 5}$ & \multicolumn{4}{|l|}{} \\
\hline
\end{tabular}

Sumber: Diolah dengan Eviews 10

Tabel 2 menunjukkan bahwa hubungan antara Pendidikan sekolah dasar, angka harapan hidup, dan jumlah penduduk terhadap produk domestic bruto sangat kuat. Hal ini ditunjukkan dengan nilai Adjusted R-Square sebesar 0.996 yang dapat disimpulkan bahwa variabel independen yaitu Pendidikan, angka harapan hidup, dan jumlah penduduk mempengaruh variabel dependen yaitu Produk Domestik Bruto sebesar 99,6\%, dan 4\% dipengaruh oleh variabel lain diluar penelitian.

Tabel 2. Hasil Pengujian Hipotesis

\begin{tabular}{|l|l|l|l|}
\hline Variabel & Coefficient & T-Statistic & Probability \\
\hline C & 20.53149 & 31.58393 & 0.0000 \\
\hline Pendidikan & $9.48 \mathrm{E}-09$ & 2.034764 & 0.0458 \\
\hline Angka Harapan Hidup & 0.066577 & 5.475130 & 0.0000 \\
\hline Jumlah Penduduk & $3.29 \mathrm{E}-09$ & 4.162967 & 0.0001 \\
\hline F-Statistik & $\mathbf{2 7 9 0 . 0 0 9}$ (Prob 0.0000) & \\
\hline Adjusted R-Square & $\mathbf{0 . 9 9 6 2 2 4}$ & \\
\hline
\end{tabular}

Sumber: Diolah dengan Eviews 10Berdasarkan hasil Uji Simultan (Uji F), variabel independen secara

bersama-sama mempengaruh variabel dependen dengan nilai sig $0.000<0.05$. oleh karena itu, dapat disimpulkan bahwa terdapat pengaruh yang signifikan antara pendidikan sekolah dasar, angka harapan hidup, dan jumlah penduduk terhadap produk domestic bruto. Berdasarkan Uji Parsial (Uji T), dapat diidentifikasi bahwa Pendidikan sekolah dasar berpengaruh positif signifikan terhadap produk domestic bruto (PDB) dengan nilai sig $0.0458<0.05$ dan t-hitung sebesar $2.0347>1.99394$. Angka harapan hidup $(\mathrm{AHH})$ berpengaruh positif signifikan terhadap produk domestic bruto dengan nilai sig $0.000<0.05$ dan t-hitung sebesar $5.475130>1.99394$. Terakhir, jumlah penduduk berpengaruh positif signifikan terhadap produk domestic bruto dengan nilai sig $0.0001<0.05$ dan t-hitung 4.1629 $>1.99394$.

\section{Pengaruh Pendidikan terhadap Pertumbuhan Ekonomi}

Hipotesis pertama pada penelitian ini adalah Pendidikan sekolah dasar berpengaruh posifit signifikan terhadap pertumbuhan ekonomi. Berdasarkan hasil hipotesis diatas, 
hipotesis pertama diterima. Pendidikan dapat meningkatkan sumber daya manusia yang akan meningkatkan produktivitas tenaga kerja dan tingkat pertumbuhan ekonomi (Habibi \& Mohamad, 2020). Kemajuan dan kemakmuran suatu negara tergantung pada pilihan Pendidikan yang tersedia bagi bangsanya. Pendidikan tidak hanya melatih manusia untuk memahami dan mengatasi kompleksitas pertumbuhan ekonomi, tetapi juga berfungsi sebagai pengungkit untuk peningkatannya (Zhua et al, 2017).

Oleh karena itu, Pendidikan menjadi salah satu alasan mengapa negara-negara maju ataupun berkembang dapat meningkatkan pertumbuhan ekonomi di negara nya. Penelitian ini sejalan dengan penelitian yang dilakukan oleh Mabrouki (2018) yang meneliti hubungan pendidikan sekolah dasar dengan pertumbuhan ekonomi. Pendidikan adalah suatu modal sumber daya manusia yang dapat dikembangkan yang mampu memperkuat tumbuhnya ekonomi negara. Penelitian lain juga mengungkapkan bahwa Pendidikan berpengaruh dalam meningkatkan pertumbuhan ekonomi (Ali et al, 2018; Hussaini, 2019; Zhu et al, 2017; Agasisti \& Alice, 2020; Adonsou, 2018; Habibi \& Mohamad, 2020; Agustin \& Hendry, 2017; Parwa \& Yasa, 2019)

\section{Pengaruh Angka Harapan Hidup (AHH) Terhadap Pertumbuhan Ekonomi}

Hipotesis kedua dalam penelitian ini adalah angka harapan hidup berpengaruh positif terhadap pertumbuhan ekonomi. Hipotesis ini diterima berdasarkan hasil pengujian hipotesis diatas. Kematian berkorelasi dengan pertumbuhan ekonomi suatu negara, negara dengan berpenghasilan tinggi biasanya memiliki tingkat kematian yang lebih rendah dari pada negara yang lebih miskin (Shkolnikov et al, 2019). Oleh karena itu, perbaikan harapan hidup dapat meningkatkan pendapatan nasional yang kemudian dapat mencerminkan pertumbuhan ekonomi yang baik.

Ada empat cara dimana peningkatan kesehatan yang diproksikan dengan angka harapan hidup dapat menyebabkan pertumbuhan ekonomi. Pertama, produktivitas, yaitu populasi yang lebih sehat cenderung secara fisik lebih energik dan lebih kuat mental. Kedua, Pendidikan, yaitu orang-orang yang hidup lebih lama memiliki inisiatif yang lebih kuat untuk berinvestasi dalam modal manusia. Selain itu, peningkatan sekolah mempromosikan produktivitas yang lebih besar sehingga meningkatkan pendapatan akan tinggi. Ketiga, investasi dalam modal fisik sejak perbaikan umur Panjang menciptakan kebutuhan yang lebih besar. Terakhir, transisi demografis dari tingkat kematian dan kesuburan yang tinggi ke yang rendah (Fioroni, 2018).

Penelitian ini sejalan dengan penelitian yang dilakukan oleh Shkolnikov et al (2019) yang mengemukakan bahwa angka harapan hidup berpengaruh positif terhadap pertumbuhan ekonomi. Penelitian lain juga menemukan bahwa angka harapan hidup berpengaruh positif terahdap pertumbuhan ekonomi (Mahamud et al, 2013; Shkolnikov el al, 2019; Muda et al, 2019). Namun, penelitian Okumade \& Ahmad (2020) tidak sejalan dengan penelitian ini karena menyatakan bahwa angka harapan hidup berpengaruh negative terhada pertumbuhan ekonomi.

\section{Pengaruh Jumlah Penduduk Terhadap Pertumbuhan Ekonomi}

Hipotesis terakhir dalam penelitian ini adalah jumlah penduduk berpengaruh positif terhadap pertumbuhan ekonomi yang mana hipoesis ini diterima. Majunya atau tidaknya suatu negara dapat dilihat dari pertumbuhan penduduknya (Peter \& Ibarahim, 2018). Pertumbuhan populasi memiliki efek yang beragam terhadap pertumbuhan dan kinerja sebuah negara. Menurut Rodriguez et al (2016), pertumbuhan populasi yang cepat dapat menyebabkan pertumbuhan ekonomi dan menimbulkan kemiskinan yang lebih rendah. Dampak positif dari populasi terhadap pertumbuhan ekonomi tergantung pada struktur usia penduduk dalam suatu negara, apalagi pada negara maju dan berkembang (Peter \& Ibrahim, 
2018). Lebih lanjut, pertumbuhan populasi yang cepat dapat menyebabkan pertumbuhan ekonomi dan kemiskinan yang lebih rendah (Rodriguez et al, 2016).

Ini menunjukkan bahwa di negara-negara dengan jumlah penduduk terbesar, pertumbuhan ekonominya dapat dilihat dari jumlah penduduk. Penelitian ini sejalan dengan penelitian yang dilakukan oleh Peter \& Ibrahim (2018) yang meneliti dampak dari populasi terhadap pertumbuhan ekonomi di negara Afrika. Hasil penelitian menemukan bahwa pertumbuhan penduduk dapat mempengaruh pertumbuhan ekonomi. Hasil penelitian lain juga menyatakan bahwa pertumbuhan penduduk dapat mempengaruhi pertumbuhan ekonomi dalam jangka Panjang (Rodriguez et al, 2016; Rahayu et al, 2017; Hasanur \& Zainar, 2017).

\section{Kesimpulan}

Penelitian ini bertujuan untuk menguji pengaruh Pendidikan sekolah dasar, angka harapan hidup, dan jumlah penduduk terhadap pertumbuhan ekonomi di 5 negara dengan jumlah terbesar di dunia yaitu China, India, Indonesia, Pakistan, dan Amerika Serikat pada tahun 2015-2019. Hasil penelitian menyatakan bahwa pendidikan sekolah dasar berpengaruh positif terhadap pertumbuhan ekonomi. Angka harapan hidup juga berpengaruh posifit terhadap pertumbuhan ekonomi. Serta, jumlah penduduk berpengaruh positif terhadap pertumbuhan ekonomi di negara-negara tersebut.

Penelitian ini mempunyai beberapa keterbatasan penelitian. Pertama, penelitian ini hanya menggunakan tiga faktor utama yang mempengaruhi pertumbuhan ekonomi yang diproksikan dengan produk domestic bruto, yaitu Pendidikan sekolah dasar, angka harapan hidup dan jumlah penduduk. Kedua, penelitian ini hanya menguji 5 negara dengan periode penelitian 5 tahun. Ketiga, penelitian ini menggunakan metode regresi data panel.

Berdasarkan hal tersebut, kami menyarankan untuk penelitian selanjutnya dapat menggunakan variabel pendidikan yang diproksikan dengan pendidikan menengah keatas, Pendidikan tinggi, akses pendidikan serta pengeluaran pemerintah di sektor Pendidikan (Adonsou, 2018). Kemudian penelitian selanjutnya juga dapat menggunakan variabel Teknologi seperti penelitian yang dilakukan oleh Habibi \& Mohamad (2020) serta menggunakan objek negara maju, berkembang, atau miskin.

\section{Daftar Pustaka}

Adonsou, Ficawoyi Donou. (2018). Technology, education, and economic growth in SubSaharan Africa. Elsevier, Telecommunications Policy. 0308-5961.

Agasisti, Tommaso \& Alice Bertoletti. (2020). Higher education and economic growth: A longitudinal study of European regions: 2000-2017. Elsevier, Socio-Economic Planning Sciences. 0038-0121.

Agustin, Arista Wahyu \& Hendry Cahyono. (2017). Pengaruh Pendidikan Tinggi dan Investasi Asing langsung Terhadap Pertumbuhan Ekonomi di Indonesia. Jurnal Pendidikan Ekonomi. Vol. 5 No. 3 (2017).

Ali, Muhammad. Abiodun Egbetokun. Monzoor Hussain Memon. (2018). Human capital, social capabilities and economic growth. Economies. 6(2). 1-18.

Fioroni, Tamara. (2018). Life expectancy and economic growth. Thesis. Department of Economics, Italy: Univesity of Pisa. 2-3.

Habibi, Fateh. Mohamad Amjad Zabardast. (2020). Digitalization, education and economic growth: A comparative analysis of middle east and OECD countries. Elsevier, Technology in Society. 63(101370). 1-9.

Hanushek, Eric A. Ludger Woessman. (2020). Education, knowledge capital, and economic growth. Handbooks in Economics. Vol. 3. 89-200. 
Hasanur, Dedek. Zainal Putra. (2017). Pengaruh jumlah penduduk dan pertumbuhan ekonomi terhadap pendapatan asli daerah (Studi kasus di kabupaten/kota kawasan barat selatan aceh). Jurnal E-Kombis. 3(2). 46-59.

Hussaini, Usman Mallam. (2019). Influence of Education towards Achieving Sustainable Economic Growth and Development in Nigeria: Considerations, Challenges and Way Forward. International Journal of Scientific Research in Science and Technology. 6(1). 115-124.

Mabrouki, Mohamed. (2018). Supporting economic growth through innovation: How does human capital influece the rate of growth?. Economics Bulletin. 38(2). 957-972.

Mahumud, Rashidul Alam. Lal B Rawal. Golam Hossain. Ripter Hossain. Nurul Islam. (2013). Impact of life expectancy on economics growth and health care expenditures: A case of Bangladesh. Universal Journal of Public Health. 1(4). 180-186.

Muda, Riyan. Rosalina Koleangan. Josep Bintang Kalangi. (2019). Pengaruh Angka Harapan Hidup, Tingkat Pendidikan dan Pengeluaran Perkapita Terhadap Pertumbuhan Ekonomi di Sulawesi Utara Pada Tahun 2003-2017. Jurnal Berkala Ilmiah Efisiensi. 19(1). 44-55.

Okunade, Albert A \& Ahmad R Osmani. (2020). Effect of life expectancy on economic growth: new results using the flexible box-cox power transformation model. Applied Economics Letters. 27(20). 2-4.

Parwa, I Gusti Ngurah Jana Loka Adi. I Gusti Wayan Murjana Yasa. (2019). Pengaruh tingkat pendidikan dan investasi terhadap pertumbuhan ekonomi dan kemiskinan di provinsi Bali. E-Jurnal EP Unud. 8(5). 945-973.

Peter, Amade \& Ibrahim H Bakari. (2018). Impact of population growth on economic growth in Africa: A dynamic panel data approach (1980-2015). Pakistan Journal of Humanities and Social Sciences. 6(4). 412-427.

Rahayu, Kuswati Indra. Michael. Siti Amalia. (2017). Pengaruh jumlah penduduk dan inflasi serta investasi swasta terhadap pertumbuhan ekonomi. Inovasi. 13(1). 39-49.

Rodriguez, Jorge Garza. Cecilia I Andrade-Velasco. Karen D Martinez-Silva. Francisco D Renteria-Rodriguez. Pedro A Vallejo-Castillo. (2016). The relationship between population growth and economic growth in Mexico. Economics Bulletin. 36(1). 97-107.

Shkolnikov, Vladimir M. Evgeny M Andreev. Rustam Tursun-zade, David A Leon. (2019). Patterns in the relationship between life expectancy and gross domestic product in Russia in 2005-15: a cross-sectional analysis. Lancet Public Health. 4. 181-88.

Zhu, Tian-Tian. Hua-Rong Peng. Yue-Jun Zhang. (2017). The influence of higher education development on economic growth: Evidence from Central China. Higher education policy. 0952-8733/17. 
